\title{
Situs Jera' Lomp'e Sebagai Sumber Belajar Sejarah Siswa Kelas X SMAN 8 Soppeng
}

\author{
Alma Paramita, Patahuddin, H. Rasyid Ridha \\ Prodi Pendidikan Sejarah Fakultas Ilmu Sosial Universitas Negeri Makassar \\ almaparamita01@gmail.com
}

\begin{abstract}
Abstrak
Penelitian ini adalah penelitian pre-experiment. Populasi penelitian ini adalah seluruh kelas X SMAN 8 Soppeng pada semester genap tahun ajaran 2018/2019 yang terdiri dari 6 kelas dan dipilih satu kelas secara acak sebagai sampel penelitian. Pengambilan data dilakukan dengan menggunakan lembar observasi keterlaksanaan pembelajaran dan tes hasil belajar (pre-test dan post-test). Teknik analisis data yang digunakan adalah teknik analisis deskriptif dan inferensial. Hasil analisis statistika deskriptif 1) rata-rata keterlaksanaan pembelajaran dengan menggunakan situs sebagai sumber belajar sejarah sebesar 3,9 (terlaksana dengan baik) 2) ratarata hasil kemampuan awal siswa (pretest) yaitu 4,77 berada pada kategori sangat rendah. Ratarata hasil belajar siswa (posttest) yaitu 8,36 berada pada kategori sangat tinggi, 3) hasil posttest menunjukkan bahwa ketuntasan klasikal tercapai yakni 23 siswa mencapai ketuntasan individu. Hasil analisis inferensial menunjukkan 1) nilai rata-rata siswa yang diajar dengan pemanfaatan situs sebagai sumber belajar sejarah lebih besar dari 70 (KKM) 2) nilai rata-rata gain ternormalisasi lebih besar dari 0,3 (kategori sedang) 3) terdapat perbedaan yang signifikan sebelum dan sesudah diberi perlakuan. Dari hasil penelitian ini dapat disimpulkan bahwa : (1) strategi guru dalam pemanfaatan situs sebagai sumber belajar sejarah adalah melalui media gambar, sebagai contoh peninggalan zaman islam, dan tugas individu (2) keterlaksanaan pembelajaran dengan pemanfaatan situs sebagai sumber belajar sejarah terlaksana dengan sangat baik (3) hasil belajar siswa sebelum pemanfaatan situs sebesar 4,772 yang berada pada kategori rendah (4) dari hasil belajar siswa terdapat peningkatan yang dapat diketahui dari nilai rata-rata post-test sebesar 8,363 yang berada pada kategori tinggi
\end{abstract}

\section{Kata Kunci:Jera’ Lompo’e, Hasil Belajar, SMAN 8 Soppeng}

\begin{abstract}
This research is a pre-experiment research. The population of this study was all of the 10th grade of SMAN 8 Soppeng in the even semester of the 2018/2019 school year consisting of 6 classes and one class was chosen randomly as a research sample. Data is collected by using an observation sheet of the implementation of learning and learning outcomes tests (pre-test and post-test). The data analysis technique used is descriptive and inferential analysis techniques. Descriptive statistics analysis results 1) average learning performance using the site as a source of learning history is 3.9 (well implemented) 2) average results of students' initial ability (pretest) of 4.77 are in the very low category. The average student learning outcomes (posttest) ie 8.36 are in the very high category, 3) posttest results indicate that classical completeness is achieved ie 23 students achieve individual completeness. The results of inferential analysis show 1) the average value of students taught by the use of the site as a source of learning history is greater than $70(\mathrm{KKM}) 2$ ) the average value of normalized gain is greater than 0.3 (medium category) 3) there is a difference significant before and after treatment. From the results of this study it can be concluded that: (1) the teacher's strategy in utilizing the site as a source of historical
\end{abstract}


learning is through the media of images, for example the relics of the Islamic era, and individual tasks (2) the implementation of learning by utilizing the site as a source of historical learning very well implemented (3) student learning outcomes before the use of the site amounted to 4,772 which are in the low category (4) of student learning outcomes there is an increase that can be seen from the average post-test score of 8.336 which is in the high category.

\section{Keyword:Jera' Lompo'e, Learning Outcomes, SMAN 8 Soppeng}

\section{A. Pendahuluan}

Setiap daerah memiliki situs sejarah yang memungkinkan masyarakatnya untuk lebih mengenal dan memahami sejarahnya masing-masing. Hal tersebut termaktub dalam UU No.11 Tahun 2010 tentang Cagar Budaya Pengertian Pasal 1 angka (1) yaitu: "cagar Budaya adalah warisan budaya bersifat kebendaan berupa Benda Cagar Budaya, Bangunan Cagar Budaya, Struktur Cagar Budaya, Situs Cagar Budaya, dan Kawasan Cagar Budaya di darat dan/atau di air yang perlu dilestarikan keberadaannya karena memiliki nilai penting bagi sejarah, ilmu pengetahuan, pendidikan, agama, dan/atau kebudayaan melalui proses penetapan”. (Undang-Undang Nomor 11 Tahun 2010 Tentang Cagar Budaya, 2010)

Membahas mengenai situs bersejarah, Soppeng merupakan salah satu wilayah yang memiliki situs bersejarah yang cukup bervariasi. Namun, pemanfaatannya sangatlah kurang terutama penduduk sekitar, situs di daerah Soppeng kebanyakan digunakan untuk keperluan ritual tanpa mengetahui sejarah dan pentingnya keberadaan situs tersebut. Salah satunya adalah Situs pemakaman Jera' Lompo'e. Situs sejarah Jera' Lompo'e merupakan peninggalan bersejarah dan sekaligus sebagai warisan budaya bagi bangsa Indonesia. Keberadaan situs ini belum dimanfaatkan secara optimal, khususnya di dunia pendidikan. Oleh karena itu, dapat dikatakan bahwa sudah waktunya dunia pendidikan memberdayakan situs sejarah Jera' Lompo'e sebagai sumber belajar sejarah guna tercapainya tujuan pembelajaran yakni membantu siswa memperoleh hasil belajar sejarah yang maksimal. Kompleks pemakaman Jera' Lompo'e dapat memberikan gambaran mengenai awal masuk dan berkembangnya Islam di Kota Soppeng.

Adapun kajian relevan dalam penelitian ini adalah Ulian Barus dan Suratno Pemanfaatan Candi Bahal sebagai Media Pembelajaran Alam Terbuka dalam Proses Belajar Mengajar (Buku), 2015 Memahami tentang pemanfatan Situs Sejarah. Objek nya adalah Candi Bahal itu sendiri yang dibahas dari berbagai macam aspek, baik ekonomi atau kepariwisataan.Dalam hal ini penulis mengetahui bahwa Candi Bahal sebagai Media Pembelajaran dan dapat dikembangkan sebagai suatu objek wisata yang menambah pendapatan daerah. (Barus \& Suratno, 2015)

Inayah Dwi Lestari, Efektifitas Pemanfaatan Situs Banjarnegara sebagai sumber belajar dalam pembelajaran sejarah pada SMAN 1 Banjarnegara \& SMAN 1 Bawang Membahas tentang fungsi situs sebagai sumber belajar sejarah Membandingkan 2 sekolah sebagai objek penelitiannya. Dalam hal ini penulis membahas tentang pemanfaatan situs banjarnegara dengan membandingkan 2 sekolah dalam penelitiannya (Lestari, 2011)

Aninda Dratiarawati, Pemanfaatan Museum Isdiman Ambarawa sebagai sumber belajar (Jurnal), 2015 Relevansi situs sebagai sumber belajar Membandingkan dua kelas untuk mengetahui minat belajar siswa antara kelas yang menggunakan museum Isdiman Ambarawa dengan yang tidak. Penulis memahami bahwa ada perbedaan minat belajar siswa antara kelas yang berkunjung ke museum dan yang tidak (Dratiarawati, 2015) 
Arif Rahman, Pemanfaatan Situs Sejarah Sebagai Sumber Belajar Sejarah di MA Al-Ma'rif Singosari Kabupaten Malang, 2017. Membahas tentang pemanfaatan situs sejarah di MA Al-Ma'rif serta proses belajar sejarah di MA Al-Ma'rif (Rahman, 2017)

\section{B. Metode Penelitian}

\section{Jenis dan Desain Penelitian}

Penelitian ini merupakan penelitian pre-experimental dengan desain penelitian one group pretest-posttest design.

\section{Lokasi dan Waktu Penelitian}

Lokasi penelitian ini adalah SMAN 8 Soppeng dengan pertimbangan sekolah tersebut pernah memanfaatkan situs Jera' Lompo'e sebagai sumber beajar sejarah dalam pembelajaran yang dilakukan. Adapun waktu penelitian ini adalah 13 Mei sampai dengan 13 Juni 2019.

\section{Populasi dan Sampel}

Populasi dalam penelitian ini adalah seluruh siswa kelas X SMAN 8 Soppeng, dengan teknik Random Sampling maka, diperoleh sampel siswa kelas X.IIS.2

\section{Variabel Penelitian}

Variabel dalam penelitian ini ada dua yakni variabel bebas dan variabel terikat. Variabel bebas diketahui adalah pemanfaatan situs Jera' Lompo'e sebagai sumber belajar sejarah sedangkan variabel terikat adalah tes hasil belajar sejarah siswa kelas X

\section{Instrumen Penelitian}

Instrumen dalam penelitian ini ada dua yakni tes hasil belajar sejarah siswa yang terdiri atas pre-test dan post-test. Dan lembar observasi keterlaksanaan pembelajaran sejarah untuk megetahui seberapa baik keterlaksanaan proses belajar dengan pemanfaatan situs Jera' Lompo'e sebagai sumber belajar sejarah.

\section{Teknik Pengumpulan Data}

Adapun teknik pengumpulan data yang dilakukan dalam penelitian ini adalah sebagai berikut:

\section{a. Observasi}

Observasi merupakan melakukan pengamatan terhadap objek penelitian. Jadi peneliti akan mengamati bagaimana proses belajar sejarah siswa SMAN 8 Soppeng dan pemanfaatan situs sejarah Jera' Lompo'e sebagai sumber belajar sejarah.

\section{b. Dokumentasi}

Analisis dokumen dilakukan untuk mengumpulkan data yang bersumber dari arsip dan dokumen baik yang berada di sekolah maupun yang berada di luar sekolah, yang ada hubungannya dengan penelitian tersebut. Studi dokumentasi merupakan suatu teknik pengumpulan data dengan menghimpun dan menganalisis dokumen-dokumen, baik dokumen tertulis, gambar, maupun tak tertulis. Dokumentasi dalam penelitian ini digunakan untuk mengumpulkan data tentang pemanfaatan situs sebagai sumber belajar sejarah.

\section{c. Wawancara}

Wawancara merupakan percakapan dengan maksud tertentu antara pewawancara dengan narasumber. Wawancara dilakukan apabila pewawancara ingin menemukan permasalahan yang harus diteliti dan menemukan hal yang lebih dalam tentang responden. Peneliti melakukan wawancara dengan orang-orang yang dapat memberikan gambaran terkait kondisi dan situasi sekolah seperti Guru Sejarah SMAN 8 Soppeng, dan Siswa SMAN 8 Soppeng.

\section{Teknik Analisis Data}

a. Analisis Statistik Deskriptif

1) Lembar Observasi Keterlaksanaan Pembelajaran

2) Tes Hasil Belajar

b. Analisis Statistik Inferensial

1) Uji Prasyarat Analisis

2) Uji Hipotesis

\section{Tinjauan Pustaka}

1. Hasil Belajar

Hasil belajar yaitu perubahanperubahan yang terjadi pada diri siswa, baik yang menyangkut aspek kognitif, afektif dan psikomotor sebagai bagian dari kegiatan belajar. Pengertian tentang hasil belajar dipertegas oleh Nawawi dalam K.Brahim yang menyatakan bahwa hasil belajar dapat diartikan sebagai tingkat keberhasilan siswa dalam mempelajari materi pelajaran di 
sekolah yang dinyatakan dalam skor yang diperoleh dari hasil tes mengenal jumlah materi pelajaran tertentu (Susanto, 2013).

\section{Situs Jera' Lompo'e}

Kabupaten Soppeng jauh sebelum masa kemerdekaan Republik Indonesia adalah sebuah kerajaan. Raja memerintah secara bergantian turun-temurun. Salah satu makam kerajaan yang terletak dalam satu kompleks disebut Makam Jera' Lompo'e. Di kompleks pemakaman ini sejumlah raja atau keturunannya dimakamkan.

Makam Jera' Lompo'e ini terletak di Kelurahan Bila, Kecamatan Lalabata sekitar $1 \mathrm{~km}$ dari kota kabupaten. Kompleks makam Jera' Lompo'e dipugar dalam 3 tahun anggaran, yaitu dimulai pada tahun anggaran 1977/1978 sampai tahun anggaran 1979/1980, oleh Proyek Pemugaran dan Pemeliharaan Peninggalan Sejarah dan Purbakala Sulawesi Selatan.

Kompleks ini meliputi areal seluas \pm 2 ha termasuk makam dan taman. Pada areal pertamanan yang ada sekarang ini dahulunya adalah merupakan kompleks pemukiman penduduk. Dengan melihat orientasi makam, maka jelas bahwa makam Jera' Lompo'e merupakan makam islam, tetapi melihat styl makam serta keletakansitus maka jelas bahwa makam islam yang ada di Kompleks Makam Jera' Lompo'e ini adalah termasuk makam yang ditata atau telah berusia cukup tua. Umur makam dapat diperhitungkan sekitar abad ke 17.

Selain itu dengan memperhatikan keletakan situs, maka dapat ditarik hipotesa bahwa makam-makam yang ada dalam komplek makam Jera' Lompo'e adalah termasuk tokoh masyarakat pada jamannya. Bentuk-bentuk nisan yang beraneka ragam menampakkan adanya pengaruh kebudayaan yang lebih dari jaman pemakaman itu terjadi (Mutallib, 1981).

3. Sumber Belajar

a. Sumber belajar menurut Association of Education Communication Technology (AECT) tahun 1997 adalah semua sumber (data, manusia, dan barang) yang dapat dipakai oleh pelajar sebagai suatu sumber tersendiri untuk memperlancar proes belajar dan meliputi pesan, orang, material, alat, teknik dan lingkungan (Marwoto, 2009)

b. Adapun fungsi sumber belajar adalah untuk memberikan kesempatan proses berasosiasi kepada anak-anak untuk mendapatkan dan memperkaya pengetahuan dengan berbagai alat, buku, narasumber, atau tempat. Penggunaan sumber belajar disesuaikan dengan tingkat kebutuhan peserta didik. Hal ini dikarenakan kebutuhan peerta didik akan pengulangan untuk menguasai kemampuan atau keterampilan tertentu. Fungsi sumber belajar yang lain adalah meningkatkan perkembangan peerta didik dalam berbahasa melalui komunikasi dengan mereka tentang hal-hal mengenai sumber belajar.

4. Macam-macam Sumber Belajar

a. Sumber belajar tercetak: buku, majalah, brosur, koran, denah, ensiklopedi, atau kamus.

b. Sumber belajar non cetak: film, slide, video, model, audio, transparansi, realita obyek.

c. Sumber belajar yang berbentuk fasilitas: perpustakaan, ruang belajar, lapangan olahraga.

d. Sumber belajar berupa kegiatan: wawancara, kerja kelompok, observasi, simulasi, permainan. Sumber belajar berupa lingkingan di masyarakat: tama, pasar, pabrik, situs bersejarah

5. Situs Jera' Lompo'e sebagai Sumber Belajar

Situs Jera' Lompo'e yakni makam RajaRaja Soppeng yang berisi informasi tentang bagaimana islam dapat masuk dan berkembang di wilayah Soppeng hanya mendapatkan segelintir perhatian dari masyarakat setempat termasuk kalangan pendidikan. Situs ini kebanyakan dikunjungi dengan alasan melakukan ziarah, atau sekadar datang mengabadikan momen tanpa memerhatikan fungsi edukatif dari keberadaan situs Jera' Lompo'e. 
Situs Jera Lompo'e ini memiliki keunikan, sebab, terdapat nisan hulu keris yang hanya dapat ditemukan di situs tersebut. Sehingga, situs Jera' Lompo'e seharusnya dimanfaatkan dengan maksimal sebagai sumber belajar khususnya wilayah Soppeng.

\section{Hasil dan Pembahasan}

1. Strategi Guru dalam Pemanfaatan Situs Sejarah Sebagai Sumber Belajar Sejarah

Memanfaatkan situs sebagai sumber belajar sejarah, memiliki berbagai keuntungan, baik bagi guru maupun peserta didik. Bagi guru, dapat menjadi inspirasi untuk terus berinovasi dalam melaksanakan kegiatan belajar mengajar, sedangkan bagi siswa dapat mengembangkan berbagai keterampilan/kemampuannya seperti kemampuan untuk berpikir kritis agar dapat aktif dalam pembelajaran sejarah.

Namun, kebanyakan guru hanya menggunakan metode ceramah atau diskusi sehingga materi terebut masih abstrak bagi siswa. Siswa hanya berangan-angan mengenai bentuk situs yang dijelaskan guru di kelas. Oleh karena itu, guru perlu mengetahui pola yang cocok dan sesuai sebagai metode pembelajaran di kelas. Dengan memanfaatkan situs peninggalan sejarah sebagai sumber belajar, pemahaman siswa yang masih abstrak bisa menjadi lebih konkret karena dapat melihat langsung materi yang selama ini dijelaskan oleh guru. Seperti kelengkapan-kelengkapan serta bentuk situs yang sebenarnya dapat dilihat secara langsung ataupun disentuh oleh siswa.

Dari hasil penelitian yang dilakukan oleh peneliti bahwa strategi guru dalam melakukan pemanfaatan situs sejarah sebagai sumber belajar adalah sebagai berikut:

\section{a. Pemanfaatan Situs Melalui Media Gambar}

Situs sejarah dapat dimanfaatkan melalui berbagai cara, salah satunya adalah media gambar. Pemanfaatan situs sejarah sebagai sumber belajar sejarah melalui media gambar ole guru SMAN 8 Soppeng dilakukan dengan cara menunjukkan gambar kemudian dijelaskan oleh guru baik melalui buku ataupun LCD.

"Pemanfaatan situs dari gambar sudah sering dilakukan baik dari buku baru saya jelaskan sedikit, anak-anak sekarang juga biasa menggunakan internet untuk mencari tau materi atau bagaimana model situsnya” (Arafah, 2018)

Pemanfaatan situs melalui media gambar yang dilakukan sudah sejak lama masih memberi gambaran semu bagi siswa untuk dapat memahami materi karena tidak dapat melihat atau menyentuh secara langsung bukti peninggalan sejarah. Hal ini releval dengan pernyataan siswa sebagai berikut:

"Kalau contoh peninggalan sejarah kak, biasa dilihat di buku paket, tapi kadang tidak terlalu kuperhatikan apalagi kalau hitam putihmi gambarnya. Kalau langsungki ke tempatnya bisaki lihat bagaimana modelnya, bebaski juga bertanya sama penjaganya, kak.” (Damayanti, 2019)

Pada dasarnya keinginan untuk menggunakan situs sejarah sebagai sumber belajar sejarah sangatlah besar, agar siswa dapat lebih memahami materi dan tertarik dengan pembelajaran sejarah bukan hanya diangkat sebagai contoh/bukti peninggalan sejarah, ataupun melalui media gambar.

\section{b. Pemanfaatan Situs Sejarah Melalui Tugas Individu \\ Pemanfaatan situs sebagai sumber} belajar sejarah dengan memberikan tugas kepada siswa untuk mengamati lingkungan sekitar dan salah seorang siswa mengangkat situs Jera' Lompo'e sebagai hasil pengamatan yang menjadi tugas individu. Berdasarkan hasil wawancara dengan Musdalifah yang mengatakan bahwa :

"Saya tidak membawa siswa datang ke situs. Tetapi, saya pernah memberi tugas pada siswa untuk mengamati lingkungan terkait dengan materi yang dipelajari, dan kebetulan ada siswa yang mengamati Situs Jera' Lompo'e.” (Arafah, 2018) (Musdalifah, 2019) 
Hal tersebut diperkuat oleh pernyataan Yeyeng Prisma Ramadhani yang mengatakan bahwa pemanfaatan situs sejarah Jera' Lompo'e sebagai sumber belajar dilakukan dengan cara pemberian tugas untuk melakukan pengamatan terhadap lingkungan sekitar tempat tinggal siswa.

"Saya dulu pernah ke sini kak (Jera' Lompo'e), untuk mengerjakan tugas dari ibu Mus” (Ramadani, 2019)

\section{c. Pemanfaatan Situs Sejarah Sebagai Bukti Peninggalan Sejarah \\ Pemanfaatan Situs Sejarah Sebagai} Bukti Peninggalan Sejarah adalah cara yang paling sederhana untuk memanfaatkan situs sebagai sumber belajar namun menjadi cara yang sukar dipahami siswa. Berbeda dengan pemanfaatan melalui media gambar siswa mendapatkan gambaran situs walau sifatnya semu sedangkan apabila dijelaskan berdasarkan pengalaman atau pengetahuan guru membuat siswa berangan-angan tentang bentuk situs, ataupun keadaan situs yang dapat mengakibatkan siswa menjadi kurang paham bahkan salah paham dengan apa yang disampaikan oleh guru. Dalam hal ini, pemanfaatan situs sebagai bukti peninggalan sejarah dilakukan dengan cara guru memberi contoh peninggalan sejarah sesuai dengan materi yang tengah diajarkan.

\section{Keterlaksanaan Model Pembelajaran}

Keterlaksanaan model pembelajaran merupakan data tentang pencapaian pengajar dalam pemberian treatment di dalam kelas, sehingga di dalam pelaksanaan pembelajaran benar-benar sesuai dengan kondisi dan proses yang diharapkan. Guru merupakan salah satu faktor yang mempengaruhi hasil pelaksanaan dari pembelajaran yang telah diterapkan, sebab guru merupakan pengajar di kelas.

Pemanfaatan situs sejarah sebagai sumber belajar sejarah adalah suatu program pembelajaran yang di desain untuk membantu guru dalam hal mengoptimalkan pembelajaran siswa dimana siswa dapat melihat langung bukti peninggalan sejarah, sehingga siswa dapat memiliki pengalaman belajar yang baru serta ikut serta aktif dalam pembelajaran.

Pemanfaaatan situs sebagai sumber belajar adalah strategi pembelajaran yang membantu siswa untuk aktif dalam pembelajaran dengan mendapatkan gambaran langsung mengenai bentuk, tataletak serta kelengkapan-kelengkapan situs yang sesuai dengan materi pembelajaran sejarah. Dari semua aktivitas guru dalam melaksanakan proses pembelajaran, keterlaksanaan pembelajaran memperoleh nilai rata-rata sebesar 3,6. Berdasarkan kategori keterlaksanaan model pembelajaran yang telah ditentukan sebelumnya terlaksana dengan sangat baik.

\section{Tes Hasil Belajar}

Hasil belajar sejarah siswa adalah tingkat penguasaan siswa terhadap materi sejarah yang dilihat dari tes hasil belajar sejarah. Dalam hal ini, pemanfaatan situs sebagai sumber belajar sejarah dikatakan efektif apabila mencapai standar ketuntasan klasikal.

Dalam pembelajaran sejarah, pemanfaatan situs sebagai sumber belajar akan mendapat perolehan pemahaman yang lebih baik mengenai materi yang dipelajarinya dengan cara mencari, menemukan dan mengembangkan faktafakta yang diperoleh dalam pembelajaran dengan memanfaatkan situ sebagai sumber belajar sejarah.

Hal ini sejalan dengan hasil penelitian yang menunjukkan bahwa hasil belajar sejarah siswa menggunakan situs sebagai sumber belajar sejarah ditinjau dari tingkat kemampuan siswa berada pada kategori tinggi dengan tingkat ketuntasan klasikal mencapai $80 \%$ serta pengetahuan siswa menunjukkan peningkatan yang signifikan setelah belajar dengan memanfaatkan situs sebagai sumber belajar, hal ini ditunjukkan oleh nilai rata-rata gain ternormalisasi siswa sebesar 0,79 yang berada pada kategori tinggi. Secara keseluruhan pembelajaran sejarah dengan memanfaatkan situs sebagai sumber belajar sejarah dapat meningkatkan kemampuan siswa dalam memahami 
materi sejarah islam di Indonesia, sub pokok Islam Masuk ke Istana Raja.

Sedangkan pada hasil analisis statistika inferensial untuk nilai post-test hasil belajar menunjukkan bahwa nilai rata-rata hasil belajar siswa SMAN 8 Soppeng dengan memanfaatkan situs sejarah sebagai sumber belajar sejarah lebih besar dari 70 (KKM). Untuk nilai gain hasil belajar menunjukkan bahwa rata-rata nilai gain ternormalisasi lebih besar atau sama dengan 0,3 (kategori sedang).

\section{E. Kesimpulan}

1. Strategi guru dalam memanfaatkan situs sebagai sumber belajar sejarah pada umumnya antara lain:

a. Pemanfaatan situs sejarah melalui media gambar.

b. Pemanfaatan situs sejarah sebagai contoh peninggalan masa lampau.

c. Pemanfaatan situs sejarah melalui tugas individu.

2. Keterlaksanaan pembelajaran menggunakan situs sejarah sebagai sumber belajar sejarah memperoleh nilai rata-rata sebesar 3,6 yang berarti pembelajaran menggunakan situs sejarah sebagai sumber belajar sejarah terlaksana dengan sangat baik.

3. Hasil belajar sejarah siswa Kelas X SMAN 8 Soppeng sebelum pemanfaatan situs sebagai sumber belajar sejarah sebesar 4,772 yang berada pada kategori rendah.

4. Hasil belajar sejarah siswa Kelas $\mathrm{X}$ SMAN 8 Soppeng setelah pemanfaatan situs sebagai sumber belajar adalah :

a. Hasil belajar sejarah seluruh siswa (100\%) kelas X IIS.2 SMAN 8 Soppeng setelah menggunakan situs Jera' Lompo'e sebagai sumber belajar sejarah lebih besar dari 70 (KKM), artinya ketuntasan hasil belajar tercapai.

b. Terdapat peningkatan hasil belajar sejarah siswa setelah diajar dengan menggunakan situs Jera' Lompo'e sebagai sumber belajar sejarah, hal ini dapat diketahui dari nilai rata-rata Post-
Test sebesar 8,363 yang berada pada kategori tinggi.

\section{DAFTAR PUSTAKA}

Arafah, S. (2018, Oktober 02). Bagaimana strategi guru dalam pemanfaatan situs melalui media gambar? (A. Paramita, Interviewer)

Barus, U., \& Suratno. (2015). Pemanfaatan Situs Candi Bahal Sebagai Media Pembelajaran Alam Terbuka. Medan: Perdana Mitra Handalan.

Damayanti, A. (2019, Mei 18). Bagaimana menurut anda pembelajaran melalui media gambar? (A. Paramita, Interviewer)

Dratiarawati, A. (2015). Pemanfaatan Museum Isdiman Ambarawa sebagai sumber belajar. Journal of History Education.

Lestari, I. D. (2011). Efektivita Pemanfaatan situs sejarah sebagai sumber belajar di SMAN 1 Bawang dan SMAN 1 Banjarnegara.

Marwoto. (2009). Strategi Guru Sejarah dalam Meningkatkan Minat Belajar Sejarah di SMAN 10 Pekanbaru. Ilmu-Ilmu Sejarah, Budaya dan Sosial, 5(14), 26-31.

Musdalifah. (2019, Mei 18). Apakah ibu pernah membawa siswa berkunjung ke situs Jera' Lompo'e? (A. Paramita, Interviewer)

Mutallib. (1981). Jera' Lompo'e. Ujung Pandang.

Rahman, A. (2017). Pemanfaatan situs sejarah di MA Al-Ma'rif.

Ramadani, Y. P. (2019, Mei 18). Apakah anda pernah berkunjung ke situs Jera' Lompo'e. (A. Paramita, Interviewer)

Susanto, A. (2013). Teori Belajar dan Pembelajaran di Sekolah Dasar. Jakarta: Prenadamedia Grup. 
